\title{
Achieving Bilateral, Regional and Global Peace and Sustainability Through Common Grounds
}

\author{
Mumtaz M. Khan ${ }^{a}$, Sobia Khurram ${ }^{b}$, Asma Tahir ${ }^{c}$ \\ ${ }^{a}$ Imperial College of Business Studies, Lahore, Pakistan \\ Email:mumtazmkpk1@gmail.com \\ ${ }^{\mathrm{b}}$ Institute of Administrative Sciences, University of the Punjab, Lahore, Pakistan \\ Email: sobia.ias@pu.edu.pk \\ ${ }^{c}$ National College of Business Administration \& Economics, Lahore, Pakistan \\ Email:asmatahirstats@gmail.com
}

\begin{tabular}{ll}
\hline ARTICLE DETAILS & ABSTRACT \\
\hline History: & The opening of Kartarpur Corridor brings forward common ground \\
Accepted 23 August 2020 & between the two countries for bilateral, regional and global peace and \\
Available Online 30 September & $\begin{array}{l}\text { sustainability. The gains of one are considered losses to the other with } \\
\text { incidents like, lock down in Indian Kashmir, Indian Citizenship Law, } \\
\text { atrocities along the Line of Control (LOC), Pulwama incident, and }\end{array}$ \\
\hline Keywords: & surgical strike. We propose that peace and sustainability process \\
Kartarpur Corridor, Spatial, & between the two countries with its roots in Kartarpur corridor as a \\
Social, Spiritual, Economics And & common ground may help in developing future global directions. Spatial, \\
Strategic Tourism Dynamics & social, spiritual, economics and strategic (SSSES) tourism dynamics of \\
& Kartarpur Corridor is our active area of focus in this study. Expanding \\
JEL Classification: & common grounds is a formula for regional and global peace. The data \\
N10, N15 & from (384 Pakistanis and 384 non-Pakistani Sikh yatrees) is collected. \\
& The analysis and the results support the hypotheses of the study and the \\
& recommendations help working in line for development of tourism for \\
DOI: 10.47067/reads.v6i3.249 & SSSES.
\end{tabular}

(C) 2020 The authors. Published by SPCRD Global Publishing. This is an open access article under the Creative Commons Attribution-

NonCommercial 4.0

Corresponding author's email address: mumtazmkpk1@gmail.com

\section{Introduction}

The history of India-Pakistan relationship is mainly based on mistrust, broken promises, unresolved issues, and unending conflicts due to impact of various factors such as ideology, a violent legacy of partition, images of the neighbor as an enemy, with unresolved issues including Kashmir (Blinkenberg, 1998). This led to the prevalence of lose-lose situation whereas, the globalization, technology orientation, democracy, prevailing of better sense demand a better solution for multi ethnic and multi sectarian co-existence with tolerance. This can be furthered through facilitation, motivation and warmth that local interpretation of law should be generalized towards secular stream of application that promotes material and religious empowerment without discrimination. Opening of Kartarpur 


\section{Review of Economics and Development Studies, Vol. 6 (3) 2020, 591-605}

corridor on Nov. 9, 2019 to facilitate millions of Sikh community residing within and outside Pakistan, especially in India and abroad is a common ground towards development of peace between the two Punjab provinces, Sikh and Muslim communities in the world (Kamboh, et al. 2018).. This common ground is a landmark to Sikh community to visit their most of holy shrines placed in Pakistan. In the past, Indian Sikh pilgrims had to undergo a 125 kilometer journey via bus from Lahore to Kartarpur whereas Gurdwara Darbar Sahib Kartarpur was made visible to the people of India by constructing a raised observation platform. The need is to explore and expand such common grounds and expand them in the world for global peace (Dányi, \& Spencer, 2019).

Sikhs men and women from all over the world are now part of the design to visit the holy shrines located at Kartarpur throughout the year in general and in September, to celebrate the death anniversary and in April, the birthday of Guru Nanak, in particular. Sikh Yatrees may spend more time visiting Nankana Sahib, Lahore and other places where these holy shrines exist. These Sikh yatrees combine different factors of ethnicity, nationality, sect, and gender that split them in real life and uphold a common identity by carrying out the same rituals and similar dressing stressing their equality.

\section{Spatial Dimension}

The impact of Kartarpur corridor on spatial, social, spiritual, economics and strategic (SSSES) tourism dynamics seems to be more interesting and valid for de-escalating the tension, mistrust, warfare etc. and may serve as a common ground and a part of the peace and sustainability process (PSP) between the two communities, two countries and the region. Spatial dimensions of SSSES of Kartarpur Corridor refer to the development of a dedicated corridor from Dera Baba Nanak in Gurdaspur district to the International Border to facilitate Sikh pilgrims visiting Kartarpur Sahib throughout the year including all modern amenities and facilities to be developed by India and to develop a similar $4 \mathrm{~km}$ corridor from International Border to Kartarpur on the historic site where Guru Nanak settled after his missionary travels. The areas along the borders of the two countries based on agricultural landscape is further developed into beautiful landscapes with the need based buildings and markets emerging around Kartarpur ranging from development of hotels, roads, food resorts, markets representing both the cultures to development of Kartarpur Darbar and Dera Baba Nanak, bringing about incarnation of new spatial dimensions of the area not known so far. This spatial dimension with the Kartarpur Corridor is important to understand as it includes in it the changes of landmarks, the changes in understanding the physical features of the communities and the changes in bringing about a better harmony among ethnic cultures. Spatial dimension is important for Pakistani and Sikh yatrees in order to understand the niche, physical features, gestures of the group members, the buildings, roads, rituals etc (Asmussen, et al. 2019). This spatial dimension has been part of the SSSES dimension in the emergence of this landscape. This paper, contributes towards highlighting a gap regarding SSSES dimensions in which group members are to be accepting of physical bearings of individual in groups, their religious pursuits, their tourism experiences, their knowledge of the niche etc. This understanding is not restricted to individual group members' knowledge of the space rather a shared understanding. This shared understanding may help in enhancing peace and sustainability process (PSP) between India and Pakistan. On the basis of our understanding of the concept of spatial dimension, we hypothesize that:

H1: Spatial dimension of Kartarpur Corridor has positive impact on PSP between India and Pakistan. 


\section{Review of Economics and Development Studies, Vol. 6 (3) 2020, 591-605}

\section{Social Dimension}

Understanding the effect of participation in the holy rituals by the pilgrims highlights not only Sikhism and its institutions, but more generally the development of beliefs and identity. Also of special interest is how this experience shapes views of fellow Sikhs as well as non-Sikhs towards. Theories of social interaction have highlighted how exposure to other groups might promote empathy or antipathy towards recipients depending upon the nature of the interaction (Pettigrew and Tropp, 2006). Also social identity literature suggests that strong attachment to a group through interaction may be combined with negative feelings toward members of out-group (Tajfel and Turner, 1986). This study however, takes the theory of social integration with understanding of the diversity by iterative interactions. It is vital to develop an understanding of how groups interact with each other including their likings/dislikings, beliefs and attitudes. Understanding this social dimension enables to understand group dynamics and aids towards their coordination (Khan, Lodhi \& Makki, 2011). Also understanding of this social dimension is not only enabled to gauge likings/dislikings of individual group members but it is also extended to the overall likings/dislikings, ultimately contributing towards determining overall synergy of the group. Hence, this paper contributes towards highlighting group dimensions where group members are supposed to understand emergence of social interactions patterns among individuals and to enhance synergy of patterns of social interactions due to constant formal and informal interaction. We extend the above argument by synergizing not only the comprehension of the social interaction processes regarding social dimension but also integration of social dimension with SSSES dimension. On the basis of this argument. Social dimensions of Kartarpur corridor refer to the interaction of the Sikh community with the rest of communities living across the borders with a collaborative approach. Sikh pilgrims are going to visit Kartarpur with their religious zeal and spiritual approach which in turn is expected to bring about emotions more associated to think positively of the rest of the communities across the borders facilitating them. This can give rise to an understanding of civil-society in both countries to focus their attention on discussing and finding ways to better interaction, coordination and cooperation. We know that the movement of Sikh community from around the globe with a view to pay tribute to the holy shrines throughout the year and a collective movement in September to celebrate his death anniversary and in April to celebrate his birthday will become a regular phenomenon. They share a common socio-cultural heritage and, it is thought that a workable relationship can certainly be developed based on peaceful co-existence. In Shakargarh, Punjab, literate peaceful residents with the traditions of hospitality can help in improving such social interactions where chances to win-win social interaction emerging in PSP between India and Pakistan may prevail. On the basis of above, we hypothesize that:

H2: Social dimension of Kartarpur corridor has positive impact on impact on PSP between India and Pakistan.

\section{Spiritual Dimension}

Spiritual dimension of SSSES in Kartarpur corridor refers to the impact of movement of Sikh yatrees with a zeal and devotion aimed at development of feelings of unity with fellow Sikhs. Numerous Sikh yatree's accounts suggest that the visit to holy shrines inspires feelings of unity with the worldwide Sikh community.

The specific landscapes in the way assume the shape of therapeutic landscapes whereby the physical and built environment, social conditions and human perceptions yield an atmosphere encouraging spiritual healing (Lopez, González, \& Fernández, 2017). We propose that participation in the religious activities such as these while also reduced participation in localized practices and beliefs increases belief in equality and harmony among ethnic groups and

may lead to more favorable 


\section{Review of Economics and Development Studies, Vol. 6 (3) 2020, 591-605}

attitudes toward the rest of them. Increased unity within the Sikh world is not accompanied by antipathy toward non-Sikhs. Instead, yatrees display increased belief in peace, and in equality and harmony among adherents of different religions. The evidence suggests that these changes are more a result of exposure to and interaction with Sikhs from around the world, rather than religious instruction or a changed social role of yatrees upon return. This spiritual interaction with their community, towards their shrines and with other communities of SSSES in Kartarpur corridor is of vital importance for developing PSP between India and Pakistan, which may further lead to global peace and sustainability. On the basis of above, we hypothesize that:

H3 Spiritual dimension of Kartarpur corridor has impact on PSP between India and Pakistan.

\section{Economic Dimension}

Pakistan-India face the problems of inequitable income distribution, high unemployment levels, and development of distortions due to defense threat perceptions To adequately address the economics needs of their people, both countries require stability in their relationship. Pakistan Government/Marketers may work with the customers via representatives of Sikh community to satisfy their needs / demand, to set parameters/ methodologies; to attract the attention of the market/international community and interest of the customer/Sikh community towards Pakistani services. Pakistan also might develop internal processes facilitating the service marketers for delivering to its customers/ Sikh community; involve the relevant Institutions / Departments; training relevant employees of institutions, keeping them motivated through teamwork programs, etc.; Pakistan's emphasis should be towards ensuring satisfaction of the Sikh community and as Sikh community exist worldwide, it will help creating positive goodwill through word of mouth for Pakistan. In order to accomplish all efforts in a successful way, good ambience for the former neighbors with similar culture should be enabled and promoted by Pakistan. The personnel of relevant institutions including foreign office, police, rangers and army might be very good towards performing their tasks through knowledge, skills and empowerment. Good service delivery should be ensured. This will help in determining the need to improve trade links between India and Pakistan in general, and the two Punjabs in particular.

Trade has played a significant role towards reducing poverty all around the world. It is the success of the strong trade relations with their neighbors which has been instrumental for the most successful nations of the East Asia, Europe, and North America. Conversely, countries of the South Asian origin have been unable to fully utilize the value offered by proximity. South Asia's total trade represents less than 6 percent of the total intraregional trade whereas the figure is about 50 percent for East Asia and the pacific and for Sub-Saharan Africa the figure stands at about 22 percent. These trade figures highlight the difference between the actual versus potential trade in South Asian region. As per an estimation of the gravity model, potentially total goods trade within south asia could be increased from current level of $\$ 23$ billion to an estimated value of $\$ 67$ billion (Kathuria, \& Mathur, 2019). As an example, current trade levels between both neighbors India and Pakistan could be increased around 15 times. The level of trade attraction between both countries, also labelled as the force of gravity is also evident in the high levels of informal trade between both countries. This Informal trade represents about 50 percent of the formal trade in South Asia. This trade could be enhanced and duplicated at other regional land borders specifically at the India-Pakistan border, where most of the trade is done informally.

Recent reform initiatives including people-to-people initiatives and focusing technical engagement between both governments may enable prioritization of economics over politics. Economic dimension of SSSES in Kartarpur corridor refer to economic activity that circles around such initiative which include the construction of roads, logistics, hotels, food markets, local handicrafts, new sky rising 


\section{Review of Economics and Development Studies, Vol. 6 (3) 2020, 591-605}

buildings, spending of yatrees, banks, exchange of goods, services, currency, etc., create continuous economic circle difficult to capture.. On the basis of these arguments, we hypothesize that:

H4: Economic dimension of Kartarpur corridor has positive impact on impact on PSP between India and Pakistan.

\section{Strategic Dimension}

Strategic dimension of SSSES in Kartarpur corridor refer to development of a peaceful region to ensure economic stability of the two provinces and the economies through wellbeing of the people; moving from conflicting nations to more coordinative and cooperative with a collaborative approach. Strategic dimension here is associated to mobility and travel, which have constantly been vital characteristics of human societies, having numerous cultural, social, religious aims and purposes. It is significant to comprehend the operation of regional small tourism business, for developing strategies for their sustained success into the future. Tourism shapes societies, bring closer the societies, provides opportunities for societies to understand themselves, helps them in modifying their view of life and finally results in an important strategy for evolution of societies and global phenomenon. They become means of socialization and identity development through transmission of socio-cultural spatial knowledge, values and attitudes across ethnicities. Strategic dimension is a process of engagement and transformation of the relationships, interests, discourses and, if necessary, the very constitution of society that encourages the continuance of violent conflict. This strategic dimension may include instituting security, establishing confidence in political process, providing initial peace dividends and increasing core national capacity. These priorities comprise of delivery of basic services such as water, sanitation, health and overall wellbeing. The societies that promote multiculturism and give rights to individuals based on various ethnicities and religious identities also promote peaceful behaviors within their populations that then becomes a national discourse for a peaceful behavior beyond national borders (Hagg and Kagwanja, 2007). It is thus a right conjecture that democracies do not fight with each other and focus on economic, political and social empowerment of their populations by practicing schema of economic development that may also mean trading with neighbors and peacefully competing in international markets through harnessing and developing such good governance practices that improve local and national competitiveness (Mousseau, 2000). This strategic dimension helps in developing tolerant behavior among people for opposing point of views and provides rational for objective analysis of historic grievances that may always be resolved by working for common interests that may include important economic concepts like poverty alleviation. This strategic dimension may collectively enable societies to reach rational conclusions and solutions that may include a discourse that promotes peace within the society and outside its national borders, which may subsequently lead to a debate on issues that can see through multiple religious, ethnic and national identities to form a common understanding that drives its motivation from common good for humanity. Rationality of common interest arising out of such interaction that can be reflective of other point of view may take economic and political biases not as a matter of grievance but as a source of healthy competition working as an incentive to implement reforms in economy or society within and outside the confine of national borders. The reforms within national border of developing countries like India and Pakistan may mean improving rule of law; better facilitation through strong regulatory authorities; improved access to international markets to trade with rest of the world; and bringing inclusive economic policies with better democratic precedence for the domestic polity (Mamoon and Murshed, 2017). The strategic dimension also focuses on socio-psychological skills that constitute self-awareness, empathy and critical judgment, which provide an important basis for the transformation based on one's own and prevailing attitudes for sustainable strategy (Khan, Lodhi \& Makki, 2011). Based on the above, we hypothesize: 


\section{Review of Economics and Development Studies, Vol. 6 (3) 2020, 591-605}

H5: Strategic dimension of Kartarpur cooridor has positive impact impact on PSP between India and Pakistan.

On the basis of preceding discussion, SSSES has impact on PSP between India and Pakistan (H1$\mathrm{H}_{5}$; PSP between India and Pakistan has positive impact on peace and sustainability in the globe (H6) and the moderating role of PSP in the region has positive effect between PSP between India and Pakistan and global peace and sustainability $\left(\mathrm{H}_{7}\right)$.

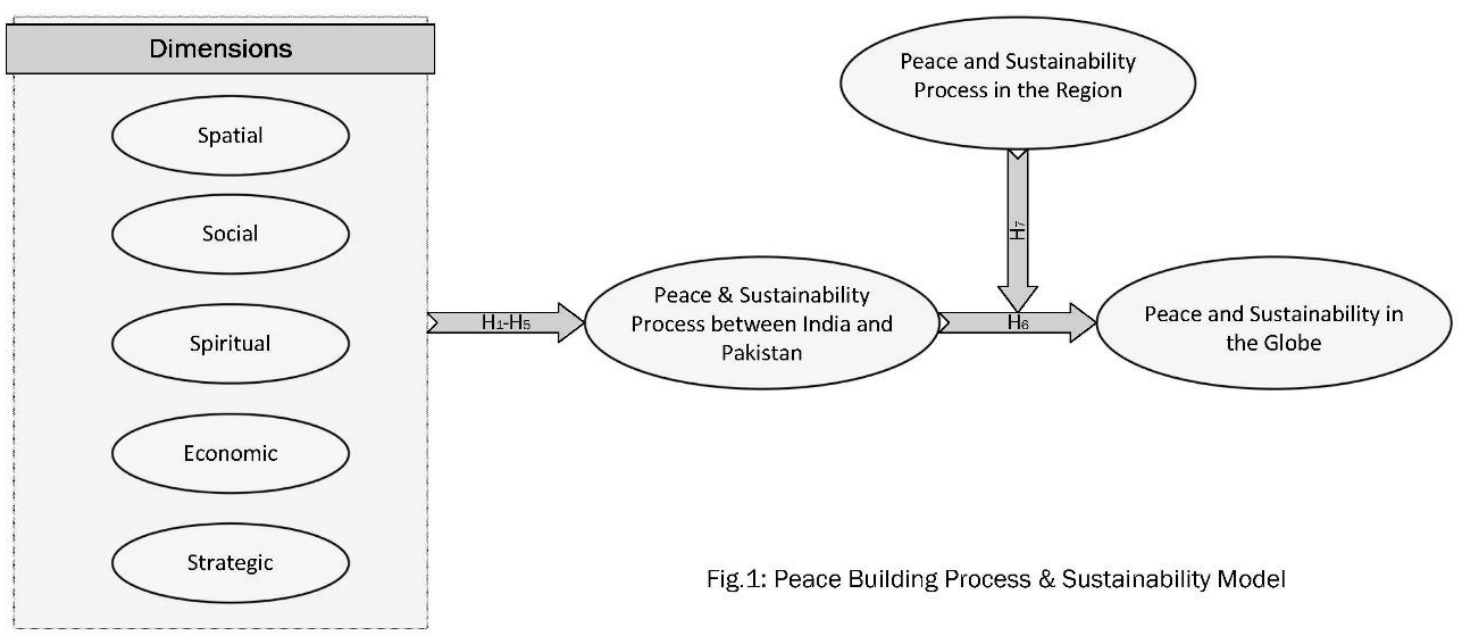

In this approach each member's knowledge at spatial, social, spiritual, economics and strategic level is measured through self-report survey items on five points Likert scale ranging from "strongly disagree (1)" to "strongly agree (5)." This approach requires specifying the relevant content described in survey items constructed to measure the variables. Accordingly, to test the hypotheses developed on the basis of our understanding and literature review, a survey is designed for 384 Pakistanis and 384 Sikh yatrees.

\section{Development of Construct}

The questionnaire is developed by going through a four phase process. In the first phase, preliminary observation of the area, communities' interaction is made to bring the study in line with the living realities. In the second phase, conduct of interviews of both the communities is conducted. In the third phase, questionnaire is pilot tested on 30 Pakistanis and 30 Sikh yatrees; and in the final phase, it is finalized by following a cyclical process of matching notes of each phase carrying out a rigorous exercise in the light of literature review. A great amount of time and energy is invested to review the items before finalizing the questionnaire divided into nine sections.

\section{Observation on Manifest And Latent Variables}

Manifest variable, which is the opposite of the latent variable, is the one which is directly measurable or observable. Latent variable, however, cannot be directly observed. Manifest variables are utilized in statistical models of latent variables testing the relationships between a set of manifest variables and a set of latent variables. Manifest variables in this construct are measured on liker scale ranging from strongly disagree 1 to strongly agree 5 . 
Table 1: Manifest and Latent Variables

\begin{tabular}{|c|c|c|}
\hline $\begin{array}{l}\text { Sr. } \\
\text { No. }\end{array}$ & Latent Variables & Manifest Variables used for Measuring \\
\hline \multirow{2}{*}{1.} & $\begin{array}{l}\text { Spatial } \\
\text { Dimension } \\
\text { Pakistanis }\end{array}$ & $\begin{array}{l}\text { Construction of road to Darbar, development of landscapes } \\
\text { in Kartarpur, development of Kartarpur area, emergence of } \\
\text { hotels, the emergence of new markets, development of } \\
\text { Darbar. }\end{array}$ \\
\hline & $\begin{array}{l}\text { Spatial } \\
\text { Dimension Sikh } \\
\text { yatrees }\end{array}$ & $\begin{array}{l}\text { The landmark when } i \text { have already seen the place, the } \\
\text { landmark when someone gives me its details, the Physical } \\
\text { appearance of the hosts, the location of hosts and holy } \\
\text { shrines. }\end{array}$ \\
\hline \multirow{2}{*}{2.} & $\begin{array}{l}\text { Social } \\
\text { Dimension } \\
\text { Pakistanis }\end{array}$ & $\begin{array}{l}\text { I feel comfortable with Sikh yatrees, make Sikh yatrees feel } \\
\text { comfortable, like their visit to holy shrines, they are } \\
\text { interesting people, they love peace. }\end{array}$ \\
\hline & $\begin{array}{l}\text { Social } \\
\text { Dimension Sikh } \\
\text { yatrees }\end{array}$ & $\begin{array}{l}\text { I feel comfortable with Pakistanis, I make Pakistanis feel } \\
\text { comfortable with me, I like them, I would like to revisit the } \\
\text { area, I like their behavior. }\end{array}$ \\
\hline \multirow[b]{2}{*}{3 . } & $\begin{array}{l}\text { Spiritual } \\
\text { Dimension } \\
\text { Pakistanis }\end{array}$ & $\begin{array}{l}\text { I respect other religions, I know that Sikhs visit here for } \\
\text { holy purposes, I respect Sikhs for their faith, I feel that } \\
\text { Sikhs are a good religious community }\end{array}$ \\
\hline & $\begin{array}{l}\text { Spiritual } \\
\text { Dimension Sikh } \\
\text { yatrees }\end{array}$ & $\begin{array}{l}\text { I am devoted to Sikhism and have respect for other } \\
\text { religions, I visit Darbar for my religious devotion, I know, it } \\
\text { helps in strengthening my spiritual being, visiting holy } \\
\text { shrines is my central areas of interest. }\end{array}$ \\
\hline \multirow{2}{*}{4 . } & $\begin{array}{l}\text { Economics } \\
\text { Dimension } \\
\text { Pakistani }\end{array}$ & $\begin{array}{l}\text { I know that Darbar has increased economic activity, we can } \\
\text { open shops and construct markets for them, we can go for } \\
\text { food restaurants, we know that jobs are available in Police, } \\
\text { Army and other departments for this tourism. }\end{array}$ \\
\hline & $\begin{array}{l}\text { Economics } \\
\text { Dimension Sikh } \\
\text { yatrees }\end{array}$ & $\begin{array}{l}\text { The jobs in Indian Dera are more available now, we can } \\
\text { open shops and construct markets for them, we can } \\
\text { increase employability in Dera area, we can take our } \\
\text { products to Darbar area. }\end{array}$ \\
\hline \multirow[t]{2}{*}{5 . } & $\begin{array}{l}\text { Strategic } \\
\text { Dimension } \\
\text { Pakistani }\end{array}$ & $\begin{array}{l}\text { I always have objective of Sikh Yatrees in mind, I give } \\
\text { regard to their religion, I help them with alternative } \\
\text { strategies to achieve their object, I select the best strategy } \\
\text { for them, I help them in possible unexpected situations. }\end{array}$ \\
\hline & $\begin{array}{l}\text { Strategic } \\
\text { Dimension Sikh } \\
\text { yatrees }\end{array}$ & $\begin{array}{l}\text { I already know the objective of my visit, I have my own } \\
\text { understanding of the visit, I understands my benefits. }\end{array}$ \\
\hline 6. & $\begin{array}{l}\text { Peace and } \\
\text { Sustainability } \\
\text { Process } \quad \mathrm{b} / \mathrm{w}\end{array}$ & $\begin{array}{l}\text { The corridor will help in development of common grounds, } \\
\text { the corridor will help in development of peace between the } \\
\text { two countries, the corridor will help in development of }\end{array}$ \\
\hline
\end{tabular}


Review of Economics and Development Studies, Vol. 6 (3) 2020, 591-605

\begin{tabular}{|l|l|l|}
\hline & $\begin{array}{l}\text { India } \\
\text { Pakistan }\end{array}$ & $\begin{array}{l}\text { sustainability between the two countries, we achieve more } \\
\text { targets when we are more communicating targets. }\end{array}$ \\
\hline 7. & $\begin{array}{l}\text { Regional Peace } \\
\text { Sustainability } \\
\text { Process }\end{array}$ & $\begin{array}{l}\text { The peace and sustainability process will help in } \\
\text { development of common grounds in the region, the peace } \\
\text { and sustainability process will help in development of peace } \\
\text { in the region, the peace and sustainability process will help } \\
\text { in development of sustainability in the region, we achieve } \\
\text { more targets when we are more communicating targets. }\end{array}$ \\
\hline 8. & $\begin{array}{l}\text { Global Peace and } \\
\text { Sustainability }\end{array}$ & $\begin{array}{l}\text { The regional peace and sustainability process will help in } \\
\text { development of common grounds for global peace and } \\
\text { sustainability, the regional peace and sustainability process } \\
\text { will help in development of Global Peace and Sustainability, } \\
\text { the regional peace and sustainability process will help in } \\
\text { development of global peace and sustainability, we achieve } \\
\text { more targets when we are more communicating targets. }\end{array}$ \\
\hline
\end{tabular}

\section{Population and Sample}

Population size in the study is fairly large as we understand that Pakistanis and Sikh yatrees can be the best judge to express their views on the study variables, as they have accurate and better understanding thereof. The Sample size (384 non-Pakistani Sikh yatrees and 384 Pakistanis on 95\% confidence level on convenient sampling basis is equally useful for generalization of the results (Raosoft, 2020).

\section{Model Testing Through Data Analysis of Survey}

The empirical validation of the model is done through ex-post facto research design. Which is useful to see the effects of independent variable or when a treatment is naturally occurring and the researcher is not interested to control the degree of its use. The researcher begins by proposing a dependent variable and then trying to find probable reasons for its occurrence as well as different explanations. Considering these observations, the data for this study is collected from the sample after conducting a survey on the basis of a developed questionnaire.

\section{Analytical Strategies - Structural Equation Modeling}

SEM is a confirmatory technique and the effectiveness of this technique requires that the model must be specified correctly based on the type of analysis that the modeler is attempting to confirm. A researcher specifies a set of theoretically plausible models to ascertain whether the proposed model is the best one out of possible models. the modeler must not only account for the theoretical reasons behind building the model as such, but they must also take into account the number of data points and the number of parameters that the model must estimate for identifying the said model. The structural equations are useful in finding out the various structures and paths in the model. Relying on the benefits associated to SEM, we decided to generate structural equations to find out the link between spatial, social and spiritual, economics and strategic dimension to peace and sustainability process.

The first five (5) hypotheses (H1) to (H5)impact of spatial dimension $(\xi)$, social dimension $\left(\xi_{1}\right)$, spiritual dimension $\left(\xi_{2}\right)$, economics dimension $\left(\xi_{3}\right)$ and strategic dimension $\left(\xi_{4}\right)$ on peace and sustainability process between India and Pakistan $\left(\eta^{1}\right)$, in seriatim are measured through: 
1. $\eta_{1}=\beta_{1} \xi+\zeta$

2. $\eta_{1}=\beta_{1} \xi_{1}+\zeta$

3. $\eta_{1}=\beta_{1} \xi_{2}+\zeta$

4. $\eta_{1}=\beta_{1} \xi_{3}+\zeta$

5. $\eta_{1}=\beta_{1} \xi_{4}+\zeta$

The 6th hypothesis predicts the impact of peace and sustainability process between India and Pakistan $\left({ }^{1}\right)$ on global peace and sustainability $\left({ }^{3}\right)$ and the final 7 th hypothesis predicts the moderating role of regional peace and sustainability process $\left(\eta^{2}\right)$ between peace and sustainability process between India and Pakistan $\left({ }^{1}\right)$ and global peace $\left({ }^{\eta 3}\right)$.

6. $\eta_{3}=\beta_{1} \eta 1+\zeta$

7. $\eta_{3}=\beta_{1} \eta 1+\eta 2+\zeta$

\section{Exogenous and Endogenous Variables}

Within SEM modeling, the exogenous variable regresses on another variable. Exogenous variables could be identified in a graphical model as the variables pointing out arrowheads towards the variable they are predicting. Whereas a variable that regresses on another variable always represents an endogenous variable, even if this same variable is utilized as a one to be regressed upon. Endogenous variables represent those variables towards which arrowheads are pointing in the models. The idea that a variable can be both independent and dependent in a SEM model makes it more robust than linear regression, as only one SEM model could be used in place of performing two regressions. Proxy measures for exogenous and endogenous variables are given in Table 1.

Table 2: Description of Symbols

\begin{tabular}{|l|l|l|}
\hline No. & Symbol & Description \\
\hline 1 & $\xi$ & Latent Exogenous Variable, Spatial Dimension \\
\hline 2 & $\xi_{1}$ & Latent Exogenous Variable, Social Dimension \\
\hline 3 & $\xi_{2}$ & Latent Exogenous Variable, Spiritual Dimension \\
\hline 4 & $\xi_{3}$ & Latent Exogenous Variable, Economic Dimension \\
\hline
\end{tabular}


Review of Economics and Development Studies, Vol. 6 (3) 2020, 591-605

\begin{tabular}{|c|c|c|}
\hline 5 & $\xi_{4}$ & Latent Exogenous Variable, Strategic Dimension \\
\hline 6 & $\eta 1$ & $\begin{array}{l}\text { Latent Endogenous Variable 1, Peace and sustainability } \\
\text { process between India and Pakistan }\end{array}$ \\
\hline 7 & $\eta 2$ & $\begin{array}{l}\text { Latent Endogenous Variable 2, Peace and sustainability } \\
\text { process in the region. }\end{array}$ \\
\hline 8 & $\eta 3$ & $\begin{array}{l}\text { Latent Endogenous Variable 3, Global peace and } \\
\text { sustainability. }\end{array}$ \\
\hline 9 & $\zeta$ & Random Disturbance Term \\
\hline
\end{tabular}

\section{Confirmatory Factor Analysis of The Construct}

The data for the study consists of 384 Pakistanis and 384 Sikh yatrees visiting holy shrines of Kartarpur Darbar. Confirmatory factor analysis (CFA) is utilized to ascertain if used measures of a construct are in line with the researcher's comprehension of the construct (or factor) nature. In contrary to exploratory factor analysis whereby all loadings are free to vary, CFA enables the clear constraint of some loadings to be equal to zero. CFA is frequently utilized in social science research (Kline, 2010). CFA is commonly utilized as a first step to ascertain the suggested measurement model in a structural equation model. In CFA factors are not assumed to be directly causing each other, whereas SEM frequently specify specific factors and variables to be causing one another. In SEM models, the CFA is frequently labelled as 'the measurement model', whereas the relationships between latent variables (signified with directed arrows) are classed as 'the structural model'.

Accordingly, CFA is conducted on spatial, social, spiritual, economics and strategic dimensions from Sikh yatrees and Pakistanis on peace and sustainability process (PSP) between India and Pakistan. PSP impact on global peace and mediating effect of PSP in the region between PSP between India and Pakistan, and global peace and sustainability.

\section{Assessment of Fit}

Utilizing the SEM program, the estimated matrices which represent the relationships between variables in the model can be compared to the actual matrices. For this purpose, formal statistical tests and fit indices have been developed. Also individual parameters of the models can be analyzed within the estimated model to gauge how well the proposed model fits the proposed theory. For goodness of fit index, this study used measures of fit reported in Table 3:

Table 3: Goodness of Fit Index for Global peace Model

\begin{tabular}{|l|l|l|}
\hline Index & Value & Criterion \\
\hline Joreskog GFI & 0.730 & $\geq .90[\mathrm{Hu}$, et al. (1999)] \\
\hline Joreskog AGFI & 0.704 & $\geq .80$ \\
\hline Steiger-Lind RMSEA Index & 0.074 & $\begin{array}{l}\leq 0.08 \quad[\mathrm{Hu} \text { and Bentler (1999); } \\
\text { Thompson (2004)] }\end{array}$ \\
\hline
\end{tabular}


Review of Economics and Development Studies, Vol. 6 (3) 2020, 591-605

\begin{tabular}{|l|l|l|}
\hline & & \\
\hline ML Chi-Square & 2716.070 & \\
\hline Degrees of Freedom & 1029.000 & \\
\hline p-level & 0.000 & \\
\hline
\end{tabular}

The results of CFA for the confirmation of spatial dimension of PSP between India and Pakistan with Pakistanis and Sikh yatrees confirm that the construct fulfills the criterion of CFA. Accordingly, this construct is in conformity with the use of Structural Equation Modeling.

\section{Path Analysis For Global Peace}

The impact of spatial, social, spiritual, economics and strategic dimension on PSP between India and Pakistan is seen as the first path. PSP between India and Pakistan impact on global peace is the second path and the moderation of regional peace and sustainability process between PSP between India and Pakistan and Global peace is the third path.

Table 4: Model Estimates for Global Peace

\begin{tabular}{|l|l|l|l|l|}
\hline & $\begin{array}{l}\text { Parameter } \\
\text { Estimates }\end{array}$ & $\begin{array}{l}\text { Standard } \\
\text { Error }\end{array}$ & T-Statistics & $\begin{array}{l}\text { Prob. } \\
\text { Level }\end{array}$ \\
\hline (Sp)-95->(PSP) & 0.308 & 0.902 & 4.056 & 0.000 \\
\hline (So)-96->(PSP) & 0.474 & 0.106 & 4.483 & 0.000 \\
\hline (Spir)-97->(PSP) & 0.405 & 0.106 & 4.483 & 0.000 \\
\hline (Eco)-99->(PSP) & 0.589 & 0.042 & 14.171 & 0.000 \\
\hline (Str)-100->(PSP) & 0.624 & 0.05 & 12.47 & 0.000 \\
\hline (PSP)-101->(GP) & 0.658 & 0.135 & 4.875 & 0.000 \\
\hline (RPSP)-102->(GP) & 0.667 & 0.107 & 6.227 & 0.000 \\
\hline
\end{tabular}

The structural path of spatial, social, spiritual, economics and strategic dimension on PSP between India and Pakistan can be seen through their coefficients (Fig-2): 


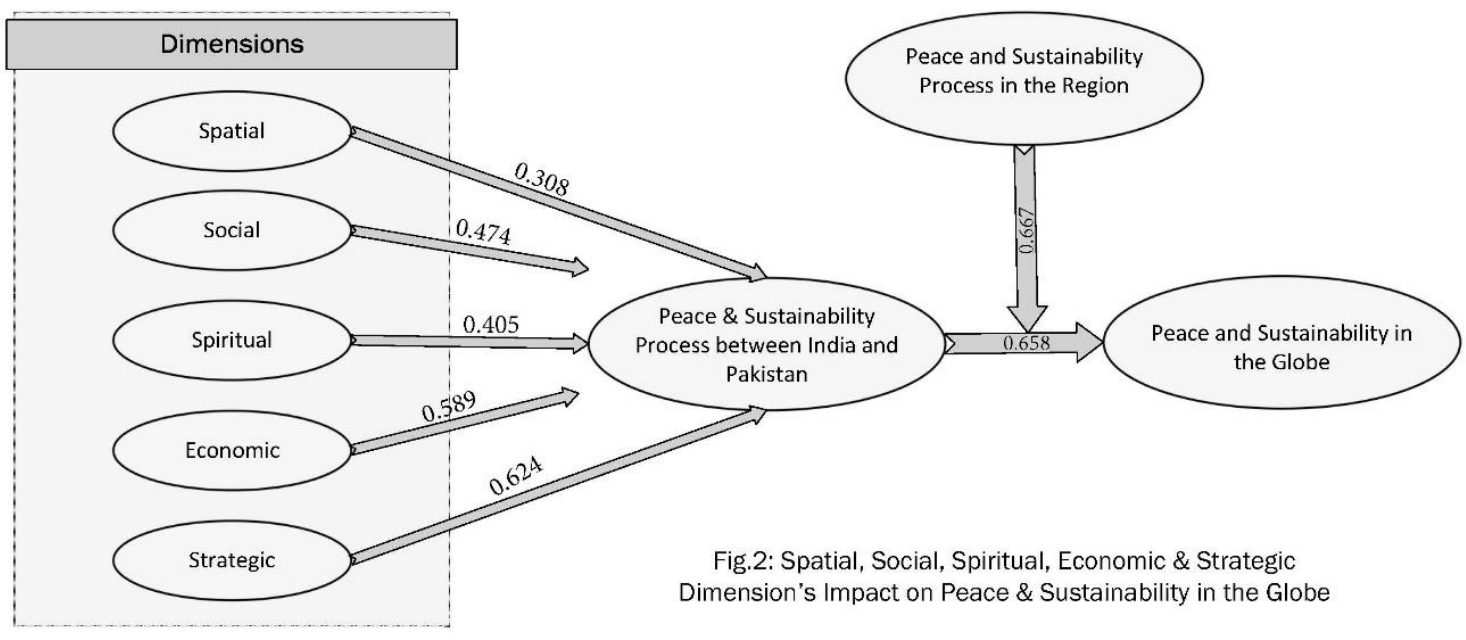

The structure of spatial, social, spiritual, economics and strategic dimension on PSP between India and Pakistan on the basis of global peace model is seen on all the three levels (Fig. 2). The following direct path of spatial, social, spiritual, economics and strategic dimension to PSP between India and Pakistan shows significant direct impact: Spatial Dimension $\rightarrow$ PSP between India and Pakistan $=0.308$, Social Dimension $\rightarrow$ PSP between India and Pakistan $=0.474$, Spiritual Dimension $\rightarrow$ PSP between India and Pakistan $=0.405$, Economics Dimension $\rightarrow$ PSP between India and Pakistan $=$ 0.589 , Strategic Dimension $\rightarrow$ PSP between India and Pakistan $=0.624$

The direct impact of strategic dimension is higher than the rest of the variables, which emphasizes the importance of strategic dimension in PSP between India and Pakistan. Surprisingly, spatial dimension (0.308) and spiritual dimension (0.405) have relatively less significant impact on PSP between India and Pakistan, as per data collected for this study. This needs to be further confirmed through future studies. The variance of impact can be viewed with reference to the relations of all these variables with PSP between India and Pakistan. The more weightage of economics and strategic is in line with our thought processes and are more significant dimensions of the model.

The path to global peace through PSP between India and Pakistan shows a significant impact of 0.658 whereas moderating role of regional peace and sustainability process between PSP between India and Pakistan and global peace shows a significant impact of 0.667 , PSP between India and Pakistan $\rightarrow$ global peace $=(0.658)$, and Moderating role of regional peace and sustainability process between PSP between India and Pakistan $\rightarrow$ global peace $=(0.667)$

\section{Results of Hypotheses Testing}

The study tests the hypotheses on the basis of strength of path coefficients by calculating multiple path values through Statistica-7. The standardized path coefficient ( $\beta$ ) displays the significance of relations between latent constructs and allow the analysis of the proposed hypotheses. Chin (1998) has suggested value of path coefficient to be at least 0.20 and ideally exceeding 0.30 to meaningfully analyze the hypothesis. All $\beta$ values of the impact of social dimension on PSP between India and Pakistan (H2) have been significant and fall between 0.308 and 0.667 . Relationship between strategic dimension and PSP between India and Pakistan ( $\left.\mathrm{H}_{3}\right)$ also shows significant $\beta$ values and remained 0.624. While, link between spatial dimension and PSP between India and Pakistan (H2) shows relatively weaker $\beta$ values (0.308).. In this way, it can be concluded that spatial dimension 


\section{Review of Economics and Development Studies, Vol. 6 (3) 2020, 591-605}

relatively exerts less significant, less consistent and weaker impact on PSP between India and Pakistan directly.

The study also tested the 6 th and 7 th hypotheses developed in the model. The $\beta$ value (0.658) of the impact of PSP between India and Pakistan (H6) on global peace and sustainability is significant and higher than 0.30 . The $\beta$ value (0.667) representing moderating role of regional peace and sustainability process in between the relationship of PSP between India and Pakistan and global peace and sustainability $\left(\mathrm{H}_{7}\right)$ is the highest significant value of the model.

Although in SEM, spatial dimension on PSP between India and Pakistan is relatively less significant but rest of all independent variables' impact on PSP between India and Pakistan is significant. Overall findings suggest that PSP between India and Pakistan can be predicted successfully through spatial, social, spiritual, economics and strategic dimension.

\section{Conclusion}

The study concludes that the global peace model conceptualized on the strong theoretical background of exploring and expanding common ground to meet the need of the global peace challenges. The understanding of development of "global peace" in the study, is another conclusion, wherein understanding of the Pakistanis and Sikh yatrees from spatial, social, spiritual, economics and strategic dimension is an advantage to achieve a desired level with its roots in common grounds.

The study advocates the advantage of the developed construct for ex-post facto research design. Thus, empirically validates this causation in real life situation, helping in providing a significant proof of the usefulness of the construct. The study further analyzed the direct structural paths between spatial, social, spiritual, economics and strategic dimension and PSP between India and Pakistan. PSP between India and Pakistan may develop global peace and the regional peace and sustainability may moderate this relation.

\section{Contribution Of The Study}

The study aimed to highlight a recent phenomenon emerging between the two atomic powers with a common ground of Kartarpur corridor. We worked on certain factors SSSES contributing towards a common ground model bilaterally, regionally and even extended it for global peace. This study focuses on holistic approach and gives an understanding that global peace requires an understanding of the mental models of the Pakistanis and Sikh yatrees from SSSES dimensions. The research reveals that the performance of SSSES on PSP between Pakistan and India is predicted and has been empirically tested and validated.

This study has also proposed guidelines for measuring global peace and suggests the usage of expost facto research for determining the causal relationship and to answer the observation. This study offers empirical support of relationship between spatial, social, spiritual, economics and strategic dimensions and PSP between India and Pakistan. It might serve as a valuable resource for peace and sustainability in the globe in future. The study uses second generation multivariate technique; Statistica based structural equation modeling particularly appropriate in causal relationship in complex situation in the area of dimension. The contribution of this research is important for both academic researchers and anthropologists. Understanding the role of SSSES dimensions in developing PSP between India and Pakistan is beneficial for deciding on finding such common grounds. 


\section{Review of Economics and Development Studies, Vol. 6 (3) 2020, 591-605}

The study supports better understanding of spatial, social, spiritual, economics and strategic dimension can enhance the likelihood of PSP between India and Pakistan. It further, identifies the impact of PSP between India and Pakistan on global peace and finally, it validates the moderating role of regional peace and sustainability process between the relationship of PSP between India and Pakistan and global peace in line with the teams' perspective (Khan, Lodhi \& Makki, 2011).

\section{Practical Implications}

Owing to important role of SSSES towards PSP between India and Pakistan, the study highlights the need to suggest guidelines for measuring spatial, social, spiritual, economics and strategic dimension and make it part of the practices for reaping the fruits of common grounds leading to global peace. In today's global world, if information regarding dimension is recognized by the policy makers, then they might be able to take effective steps towards enhancing global peace and facing the challenges present today.

The study may be useful for anthropologists to pay attention to use this model for peace and sustainability process by finding such common grounds in the globe. The study provides a proof of importance of SSSES dimensions for PSP between India and Pakistan and ultimately, global peace.

\section{LIMITATIONS AND FUTURE RESEARCH DIRECTIONS}

This study is based on data collected from Pakistanis and Sikh yatrees at Kartarppur Darbar. The bilateral, regional and global peace requirements may vary in different regions. Such variance needs to be accommodated. The longitudinal study in this direction is another limitation of the study. The analysis of social networks for the global peace is another limitation of the study.

The study's contribution to recent literature can be maximized in various ways. One area for future research might involve analyzing he difficulty and effectiveness of various approaches towards speedily increasing global peace. Rapid development of global peace would be of considerable importance for all ethnic groups for creating bilateral and multilateral impact on global peace. Exploring and expanding the scope of common grounds seems to be winning formulae.

Research in global peace may highlight relevant features including groups requiring understanding of physical features, social interactions, spiritual integration, economics avenues and strategic decision making separately or the degree to which they can be made part of the group functioning from a collaborative approach. The construct may need to be tested on the basis of different cultures, contexts and environments. The different combinations of explanatory variables independently and collectively can be seen for their impact on bilateral peace. Another area where future research might focus for this framework of global peace includes development of global and specific construct. Finally, this theoretical model might also be empirically analyzed by utilizing the use of social network analysis, neural network analysis, experimental design, for its measurement, analysis and further validation.

\section{References}

Asmussen, C. G., Nielsen, B. B., Weatherall, C. D., \& Lyngemark, D. H. (2019). Foreign ownership and global city characteristics: unpacking the connectivity of micro-locations. Regional Studies, 1-14.

Bellman, S., Forster, N., Still, L., \& Cooper, C. L. (2003). Gender differences in the use of social support as a moderator of occupational stress. Stress and Health: Journal of the International Society for the investigation of Stress, 19(1), 45-58.

Blinkenberg, L. (1998). India-Pakistan: the history of unsolved conflicts. The historical part (Vol. 1). 


\section{Review of Economics and Development Studies, Vol. 6 (3) 2020, 591-605}

Odense University Press.

Chin, W. W. (1998). Commentary: Issues and opinion on structural equation modeling.

Cohen-Tannoudji, C., Dupont-Roc, J., \& Grynberg, G. (1998). Atom-photon interactions: basic processes and applications. Atom-Photon Interactions: Basic Processes and Applications, by Claude CohenTannoudji, Jacques Dupont-Roc, Gilbert Grynberg, pp. 678. ISBN o-471-29336-9. Wiley-VCH, March 1998., 678.

Dányi, E., \& Spencer, M. (2019). Un/common grounds: Tracing politics across worlds. Social Studies of Science.

Hagg, G., \& Kagwanja, P. (2007). Identity and peace: reconfiguring conflict resolution in Africa. African Journal on Conflict Resolution, 7(2), o9-36.

Hu, L. T., \& Bentler, P. M. (1999). Cutoff criteria for fit indexes in covariance structure analysis: Conventional criteria versus new alternatives. Structural equation modeling: a multidisciplinary journal, 6(1), 1-55.

Kamboh, A. Z., Kamal, Y., Nisar, Q. A., \& Kamboh, M. A. (2018). Kartarpur Corridor: A New Role for Political Marketing. Journal of Indian Studies, 4(2), 233-238.

Kathuria, S., \& Mathur, P. (2019). How Can South Asia Turn Its Proximity from a Burden to an Advantage?

Khan, M. M., Lodhi, S. A., \& Makki, M. A. M. (2011). Cog-synergy: A model for high performance teams. International Journal of Academic Research, 3(5).

Lopez, L., González, R. C. L., \& Fernández, B. M. C. (2017). Spiritual tourism on the way of Saint James the current situation. Tourism Management Perspectives, 24, 225-234.

Mamoon, D., \& Murshed, S. M. (2017). When Education Explains Strong Institutions: Trade Policy also Matters. Social Indicators Research, 131(3), 1179-1210.

Perkins, R., \& Khoo-Lattimore, C. (2019). Friend or foe: Challenges to collaboration success at different lifecycle stages for regional small tourism firms in Australia. Tourism and Hospitality Research, 1467358419836719. Pettigrew, T. F., \& Tropp, L. R. (2006). A meta-analytic test of intergroup contact theory. Journal of personality and social psychology, 9o(5), 751.

Raosoft, 2020. Retrieved January, 10, 2020 from http://www.raosoft.com/samplesize.html.

Tajfel, H., \& Turner, J. (1986). The social identity theory of intergroup behaviour. u: Worchel S. i Austin WG (ur.) Psychology of intergroup relations. Chicago: Nelson Hall, 7-24.

Thompson, B. (2004). Exploratory and confirmatory factor analysis: Understanding concepts and applications. Washington, DC, 10694-0oo. 